\title{
Implementasi Bantuan Hukum Oleh Notaris Secara Cuma-Cuma Kepada Orang Yang Tidak Mampu
}

\author{
Fikri Aulia \\ Magister Kenotariatan Fakultas Hukum Universitas Islam Indonesia Yogyakarta Indonesia \\ Jln. Cik Di Tiro No. 1 Yogyakarta Indonesia \\ fikri.aulia1712@gmail.com
}

\begin{tabular}{ll}
\hline Key Word: & Abstract \\
Free legal aid, & The categorization of free legal aid is not only found in the final result of the deed \\
& made, but when someone comes to consult the final result without a deed, then it \\
also includes as free legal aid because a Notary is not possible to collect honorarium \\
from the results of the knowledge that they have. Sanctions made to bring down \\
Notaries who do not carry out the mandate of Article 37 paragraph (1) of Law \\
Number 2 of 2014 on Notary Positions (UUJN) are also not implemented properly. \\
This is because there are no people who submit an application to the Notary \\
Supervisory Council that the community is not served well by the Notary. The \\
purpose of this research is to examine how the implementation of legal aid by a \\
notary for free to people who cannot afford it. The nature of this research is empirical \\
juridical, by using a statute and a qualitative approaches, the method used to collect \\
data is literature study and interviews. In this study, there are several theories used, \\
including implementation theory, code of ethics, law enforcement and sanctions, \\
Notary Public, Notary Supervisory Council. From the research results, there is no \\
classification on how people can be assisted free of charge by a Notary
\end{tabular}

\begin{tabular}{l} 
Kata-kata Kunci: \\
\cline { 3 - 3 } Jasa \\
Notaris dan jasa \\
hukum \\
cuma
\end{tabular}

\section{Abstrak}

Kategorisasi bantuan hukum secara cuma-cuma bukan hanya terdapat pada hasil akhir akta yang dibuat, tapi ketika seorang datang untuk berkonsultasi dengan hasil akhir tanpa akta, maka itu juga termasuk bantuan hukum secara cuma-cuma, karena seorang Notaris tidak mungkin memungut honorarium dari hasil disiplin ilmu yang dimilikinya. Sanksi yang dibuat untuk menjatuhkan para Notaris yang tidak melaksanakan amanat Pasal 37 ayat (1) Undang-Undang Nomor 2 Tahun 2014 tentang Jabatan Notaris (UUJN) juga tidak diimplementasikan secara baik. Hal ini dikarenakan tidak adanya masyarakat yang mengajukan permohonan ke Majelis Pengawas Notaris bahwa masyarakat tersebut tidak dilayani secara baik oleh Notaris. Tujuan dari dilakukannya penelitian ini adalah untuk mengkaji bagaimana implementasi bantuan hukum oleh Notaris secara cuma-cuma kepada orang yang tidak mampu. Sifat dari penelitian ini adalah yuridis empiris, dengan menggunakan metode pendekatan undang-undang (statute approach) dan pendekatan kualitatif, cara yang digunakan untuk mengumpulkan data adalah dengan studi pustaka serta wawancara. Dalam penelitian ini terdapat beberapa teori yang digunakan, antara lain teori implementasi, kode etik, penegakan hukum dan sanksi, Notaris, Majelis Pengawas Notaris. Dari hasil penelitian, belum ada klasifikasi tentang bagaimana orang yang dapat dibantu secara cuma-cuma oleh Notaris 


\section{Pendahuluan}

Indonesia adalah negara berkembang yang dapat dikatakan masyarakat berekonomi rendahnya masih banyak. Menurut Badan Pusat Statistik (BPS), persentase penduduk miskin pada Maret 2019 adalah 9,41\% atau sebanyak 25,14 juta. ${ }^{1}$ Namun Pada September 2019 jumlah orang miskin atau tidak mampu di Indonesia turun sebanyak 0,19\% atau sejumlah 24,79 juta. ${ }^{2}$ Artinya masih sangat banyak masyarakat Indonesia yang harus dibantu dalam segala macam aspek kehidupan, baik itu pendidikan, ekonomi, kesehatan dan hukum. Karena dengan kurangnya perekonomian yang mereka alami, dapat dipastikan beberapa aspek seperti yang disebutkan di atas sulit untuk terpenuhi sebagaimana mestinya.

Perlindungan hukum adalah kebutuhan yang harus didapat oleh semua warga masyarakat Indonesia. Walaupun hukum bukan seperti sandang, pangan, papan yang notabenenya kebutuhan primer, tapi hukum adalah hal yang sejatinya dibutuhkan semua orang untuk jalannya kehidupan yang adil. Karena adil itu bukan saat si kaya menang dan si miskin kalah, tapi siapapun yang berbuat salah itulah yang harus diberi hukuman, dan ini salah satu cara untu kmewujudkan cita-cita negara yang terdapat dalam Pancasila sila ke-4 yaitu 'kemanusiaan yang adil dan beradab'.

Jika membicarakan tentang hukum maka pengertian tentang hukum yang paling mudah untuk dimengerti adalah sekumpulan peraturan atau kaidah dalam suatu kehidupan bersama, keseluruhan peraturan tentang tingkah laku yang pelaksanaannya dapatdipaksakan dengan memberikan sanksi. Hukum yang berisikan peraturan atau kaidah mempunya isi yang bersifat umum dan normatif, maksud umum adalah berlaku untuk semua orang dan normatif karena menentukan apa yang seharusnya dilakukan, apa yang tidak boleh dilakukan atau harus dilakukan serta menentukan bagaimana caranya melaksanakan kepatuhan pada kaidah-kaidah. Hubungan hukum muncul karena adanya hak dan kewajiban. Kedua hal ini berbeda, yaitu timbul jika hukum itu diterapkan terhadap peristiwa konkret. Namun begitu keduanya tidak dapat dipisahkan. ${ }^{3}$

Islam sendiri mengajarkan tentang bagaimana akhlak dalam bernegara. Salah satu hal yang harus ditegakkan adalah keadilan. Adil berasal dari kata 'adl yang memiliki arti sama dan seimbang. Dalam pengertian pertama, adil dapat diartikan dengan sama banyak atau memberikan hak yang sama kepada orang-orang atau kelompok dengan status yang sama. Dalam pengertian kedua keadilan dapat diartikan dengan memberikan hak seimbang dengan kewajiban, atau memberikan seseorang sesuai dengan kebutuhannya. Misalnya orang tua yang adil akan membiayai pendidikan anak-anaknya sesuai dengan tingkat kebutuhan masing-masing sekalipun secara nominal setiap anak tidak akan mendapatkan nominal yang sama.

${ }^{1}$ https://www.bps.go.id/pressrelease/2019/07/15/1629/persentase-penduduk-miskin-maret-2019sebesar-9-41-persen.html, Akses 25 September 2019.

2https://www.suara.com, Akses 22 Maret 2020.

${ }^{3}$ Sudikno Mertokusumo, Mengenal Hukum Suatu Pengantar, Cetakan Kelima, Liberty, Yogyakarta, 2007, hlm. 40 . 
Notaris adalah pejabat umum yang bertugas membuat akta otentik dan tugas lain yang ditentukan peraturan perundang-undangan. Notaris dikenal sebagai pejabat umum dan bukan sebagai pejabat publik atau pejabat Tata Usaha Negara. Tugas utama seorang Notaris berada pada ranah hukum privat, membuat akta atau perjanjian antara sesama masyarakat, atau masyarakat dengan pemerintah. Pentingnya kedudukan Notaris dalam masyarakat adalah terkait dengan akta yang dibuatnya, akta yang dibuat oleh Notaris berkedudukan sebagai bukti yang sempurna. ${ }^{4}$ Istilah pejabat umum merupakan terjemahan dari istilah Openbare Ambtenaren yang terdapat dalam Pasal 1 Peraturan Jabatan Notaris (PJN). Istilah Openbare Ambtenaren yang terdapat dalam Pasal 1 Reglement op het Notaris Ambt in Indonesia (Ord. van Jan. 1860) Staatsblad 1860 Nomor 3, diterjemahkan menjadi Pejabat Umum oleh G.H.S. Lumbang Tobing, sebagaimana tersebut dalam kata pengantar bukunya "Peraturan Jabatan Notaris". Demikian pula istilah Openbare Ambtenaren yang terdapat dalam Pasal 1868 Kitab Undang-Undang Hukum Perdata (Burgerlijk Wetboek) diterjemahkan menjadi Pejabat Umum oleh R. Subekti dan R. Tjitrosudibio dalam Kitab Undang-Undang Hukum Perdata terjemahan mereka. ${ }^{5}$

Dalam hal ini pemberian jasa dan pelayanan hukum dapat diartikan sama. Pada Kamus Besar Bahasa Indonesia (KBBI), pemberian adalah menyediakan (melakukan dan sebagainya) serta pelayanan adalah perihal atau cara melayani. Pada dasarnya kedua hal di atas adalah memberikan sesuatu. Pelayanan hukum perlu diatur agar tidak adanya diskriminasi berdasarkan tingkat penghasilan, kekayaan dan sumber daya lainnya. ${ }^{6}$ Dari banyaknya pengertian bantuan hukum yang ada, terdapat kesamaan prinsip yang dapat ditarik kesimpulan, bahwa bantuan hukum adalah suatu hak yang mana sesuatu yang dapat dituntut oleh setiap subjek hukum bilamana ia memerlukannya dan pemenuhannya tersebut merupakan suatu kewajiban. Bagi orang yang mampu tentu saja ini bukan suatu hal yang sulit, bila dari hak yang ia dapat diwajibkan untuk membayar ongkos yang ada, maka ia langsung bisa membayarnya.7 Namun, bagaimana dengan masyarakat yang miskin atau tidak mampu?

Notaris disebut sebagai profesi karena di dalam diri seorang Notaris harus memiliki keilmuan yang tinggi tentang hukum, terutama hukum perdata. Dengan ilmu yang ada itulah Notaris wajib menggunakannya untuk kepentingan banyak orang, tidak semata-mata hanya mencari uang namun juga mencari pemaknaan atau panggilan hidup melalui pelayanan kepada masyarakat. Profesi yang mereka lakukan juga merupakan aktualisasi diri untuk menyatakan kebebasan, kehormatan, dan tanggungjawab. Itulah hal dasar yang membedakan pekerjaan dan profesi. ${ }^{8}$

Pekerjaan Notaris adalah pekerjaan yang lebih mengutamakan pelayanan dari pada imbalan (pendapatan). Artinya mengutamakan apa yang harus dikerjakan sebagaimana

${ }^{4}$ Syafi'ie, Ragam Profesi Hukum di Inodnesia, Cetakan Pertama, Pintu Publishing, Yogyakarta, 2016, hlm. 91.

${ }_{5}^{5}$ Ghansham Anand, Karakteristik Jabatan Notaris di Indonesia, Cetakan Pertama,: Prenadamedia Group, Jakarta, 2018, hlm. 13.

${ }^{6}$ Abdurrahman, Aspek-Aspek Bantuan Hukum di Indonesia, Cetakan Pertama, Cendana Pers, Jakarta 1983, hlm. 18.

${ }^{7}$ Abdurrahman, Ibid., hlm. 21.

8 Pengurus Pusat Ikatan Notaris Indonesia, Jati Diri Notaris Notaris Indonesia, PT Gramedia Pustaka, Jakarta, 2008, hlm. 194. 
kewajibannya bukan berapa bayaran yang akan diterima, kepuasan klien adalah yang utama. Seorang profesi selalu bekerja dengan baik, benar dan adil. Baik artinya teliti, tidak asal kerja, tidak sembrono. Benar artinya diakui oleh profesi yang bersangkutan. Adil artinya tidak melanggar hak pihak lain dan tidak memihak.9Sebagaimana telah diuraikan di atas, bahwa Notaris adalah profesi-profesi kepercayaan lainnya seperti dosen, dokter dan pengacara, mereka adalah pengemban profesi yang mempunyai tujuan utama untuk melayani kepentinga nmasyarakat. Namun walaupun bukan tujuan utama, mereka memperoleh penghasilan berupa honorarium sebagai bentuk penghargaan atau imbalan atas pelaksanaan tugas mereka sebagaimana yang telah ditentukan dalam peraturan perundang-undangan.

Honorarium berasal dari kata Honor yang artinya kehormatan, kemuliaan, tanda hormat/penghargaan semua mengandung pengertian balas jasa para nasabah. Kemudian pengertian berubah menjadi uang imbalan atau jasa atau hasil pekerjaan seseorang yang tidak berupa gaji tetap. Keahlian atau kewenangan yang dimiliki seorang Notaris sesungguhnya dapat dimanfaatkan untuk memperoleh uang atau kekayaan, namun dalam melaksanakan tugas profesinya, Notaris tidak semata-mata didorong oleh pertimbangan kekayaan, terpengaruh oleh jumlah uang, dan tidak hanya semata-mata menciptakan alat bukti formal untuk mengejar adanya kepastian hukum, namun mengabaikan rasa keadilan. Seorang Notaris harus tetap berpegang teguh kepada rasa keadilan yang hakiki dan melakukan tugas utamanya, yaitu melayani masyarakat. Namun yang perlu diingat pula di balik semua hal yang dijelaskan sebelumnya, seperti kewajiban Notaris dalam memberikan jasa hukum dan tidak berorientasi hanya karena uang, ada unsur profesionalisme agar bisa menjadi alasan untuk mendapatkan suatu penghargaan atas apa yang telah dilakukan Notaris, yaitu honorarium. ${ }^{10}$

Jadi dari uraian rumusan masalah di atas, banyak hal yang kiranya bertentangan antara kewajiban Notaris dalam memberikan jasa cuma-cuma kepada masyarakat yang tidak mampu dengan bagaimana standarisasi dari orang yang dikategorikan tidak mampu agar bisa mendapatkan bantuan Notaris. Karena yang menjadi kekhawatiran, orang bisa saja datang ke Notaris dengan mengaku bahwa dia orang tidak mampu, lalu mendapatkan bantua Nnotaris secara cuma-cuma. Sehingga hal ini diangkat agar terjadi kejelasan bagaimana implementasi dari kewajiban Notaris yang tertera dalam Pasal 37 ayat (1) Undang-Undang Nomor 2 Tahun 2014 tentang Perubahan Atas Undang-Undang Nomor 30 Tahun 2004 tentang Jabatan Notaris serta bagaimana implementasi pemberian sanksi bagi Notaris yang tidak melakukan kewajiban ini sebagaimana yang tertera dalam Pasal 37 ayat (2) Undang-Undang Nomor 2 Tahun 2014 tentang Perubahan Atas UndangUndang Nomor 30 Tahun 2004 tentang Jabatan Notaris.

\section{Rumusan Masalah}

Berdasarkan uraian dalam latar belakang di atas, selanjutnya dapat dirumuskan permasalahan, yakni: pertama, bagaimana implementasi pemberian jasa hukum secara cuma-cuma oleh Notaris kepada orang tidak mampu? Kedua, apakah penegakkan

\footnotetext{
${ }^{9}$ Ghansham Anand, Op. Cit., hlm. 107

${ }^{10}$ Ghansham Anand, Ibid., hlm. 112.
} 
pemberian sanksi terhadap Notaris yang tidak memberikan jasa hukum secara cumacuma kepada orang tidak mampu dapat ditegakkan?

\section{Tujuan Penelitian}

Bertitik tolak dari rumusan masalah di atas, adapun tujuan dari penelitian ini secara umum adalah: pertama, untuk mengkaji dan menganalisis bagaimana implementasi pemberian jasa hukum secara cuma-cuma oleh Notaris kepada orang tidak mampu. Kedua, untuk mengkaji dan menganalisis bagaimana penegakkan pemberian sanksi terhadap Notaris yang tidak memberikan jasa hukum secara cuma-cuma kepada orang tidak mampu.

\section{Metode Penelitian}

Dalam penelitian ini metode yang akan digunakan adalah yuridis empiris yakni dilakukan dengan melihat kenyataan yang ada dalam praktek di lapangan. Dengan kata lain penelitian ini melihat fakta-fakta secara langsung di lokasi penelitian, serta mencari keterangan dari pihak yang bersangkutan atau yang mengetahui kejadian atau masalah yang sedang diteliti tersebut, juga melalui observasi / pengalaman yang Penulis ketahui langsung kemudian dikaitkan dengan aspek hukum yang berlaku.

\section{Hasil Penelitian dan Pembahasan}

\section{Implementasi Pemberian Jasa Hukum secara Cuma-Cuma oleh Notaris Kepada Orang Tidak Mampu}

Pemberian jasa hukum secara cuma-cuma diamanatkan dalam ketentuan UndangUndang Nomor 16 Tahun 2011 tentang Bantuan Hukum. Pasal 1 angka 1 UndangUndang Nomor 16 Tahun 2011 tentang Bantuan Hukum menyebutkan bahwa, "bantuan hukum adalah jasa hukum yang diberikan oleh pemberi bantuan hukum secara cumacuma kepada penerima bantuan hukum". Pasal 1 ayat (3) UUD 1945 ditegaskan bahwa Indonesia merupakan negara hukum. Sebagai konsekuensi dari negara hukum, hak untuk mendapatkan bantuan hukum harus diberikan oleh negara dan itu merupakan jaminan perlindungan terhadap hak asasi manusia. Oleh karena itu dengan adanya Undang-Undang Nomor 16 Tahun 2011 tentang Bantuan Hukum diharapkan dapat melindungi hak konstitusional setiap individu untuk mendapatkan bantuan hukum selain itu juga diharapkan dapat mengakomodir perlindungan terhadap masyarakat yang kurang mampu dalam menghadapi kasus-kasus hukum. Pengakuan dan jaminan terhadap asas equality before the law ini tidak saja sebatas pengakuan politik negara saja. Akan tetapi lebih mengedepankan tindakan konkrit negara dalam memberikan jaminan kepada masyarakat dalam mendapatkan akses terhadap keadilan guna terpenuhi hakhak dasar manusia (HAM), bahkan tindakan afirmatif juga harus dilakukan untuk menjamin terselengaranya kewajiban negara ini. Dengan derasnya laju pertumbuhan pembangunan dan politik di Indonesia memunculkan permasalahan-permasalahan mendasar yang meminggirkan bahkan mengabaikan hak-hak dasar manusia yang berujung kepada kriminalisasi dan memposisikan rakyat untuk meminta hak atas 
keadilan di pengadilan maupun di luar pengadilan guna mendapatkan keadilan. Bantuan hukum adalah hak konstitusional setiap warga.

Selain amanat dalam Undang-Undang Nomor 16 Tahun 2011 tentang Bantuan Hukum, Notaris dalam menjalankan tugas jabatannya diwajibkan untuk memberikan jasa hukum secara cuma-cuma kepada masyarakat yang tidak mampu, yang dimana ketentuan tersebut diamanatkan dalam ketentuan Pasal 37 ayat (1) UUJN dan dapat berimplikasi hukum bagi Notaris apabila tidak melaksanakannya. Ketentuan pasal tersebut sudah tentu memiliki makna filosofis yang mendalam, dimana pembuat undang-undang tersebut dengan sukarela tetap mencoba memfasilitasi kepentingan dan kesetaraan setiap individu di mata hukum. Mengingat juga pentingnya bantuan hukum dalam menciptakan keadilan, menegakkan HAM, dan equality before the law, serta dalam mencapai due process of law, tentu menjadikan kewajiban pemberian bantuan hukum menjadi hal yang penting untuk dapat dilaksanakan secara efektif.

Notaris merupakan profesi hukum, dengan demikian profesi Notaris adalah suatu profesi mulia (officium nobile). Disebut sebagai officium nobile dikarenakan jabatan Notaris sangat erat hubungannya dengan kemanusiaan. Akta yang dibuat oleh Notaris dapat menjadi alas hukum atas status harta benda, hak dan kewajiban seseorang. Kekeliruan atas akta Notaris dapat menyebabkan tercabutnya hak seseorang atau terbebaninya seseorang atas suatu kewajiban.11 Bagi Notaris sendiri dalam menjalankan tugas jabatannya sudah tentu memiliki aturan-aturan yang tidak hanya perlu dipahami tapi wajib diimplementasikan. Memberikan pelayanan dengan baik, memuaskan, independen yang mana artinya tidak berat sebelah karena Notaris tidak termasuk pihak dalam setiap transaksi klien yang datang kepadanya, maka dari pada itu Notaris harus berdiri di tengah-tengah. Semua produk yang dikeluarkan Notaris, baik itu berupa akta harus dijadikan produk yang kiranya membuat klien aman, aman bukan hanya pada saat akta selesai dibuat, tapi aman hingga kapanpun. Karena akta yang dibuat Notaris adalah undang-undang bagi kedua pihak yang telah sepakat.

Terkait dengan pemberian jasa hukum secara cuma-cuma kepada masyarakat yang tidak mampu, Penulis melihat bahwa perlunya memahami kategori-kategori seseorang dapat dikatakan tidak mampu, hal ini penting sebab Notaris juga dituntut untuk jeli dan dapat mengenali penghadap yang datang kepadanya. Kategori orang yang tidak mampu sendiri dapat dibedakan menjadi 2, yakni tidak mampu secara fisik dan tidak mampu secara finansial. Artinya jika seorang yang datang ke Notaris mampu secara fisik tetapi tidak mampu karena kekurangan secara finansial, maka orang tersebut dapat dibebaskan honorariumnya.

Pasal 37 UUJN adalah sesuatu yang memang wajib dilaksanakan, namun dalam implementasinya untuk menentukan seseorang layak atau dapat dibebaskan dari biaya merupakan penilaian pribadi Notaris yang bersangkutan. Sebab mustahil bagi Notaris untuk meneliti atau mensurvey status ekonomi seseorang dengan jeli dalam waktu yang singkat. Adapun hal yang biasanya atau dapat oleh Notaris dilakukan ialah menggali informasi dari penghadap (klien) dengan melakukan dialog secara langsung, kemudian hlm. 7.

${ }^{11}$ Abdul Ghofur, Lembaga Kenotariatan Indonesia, Perspektif Hukum dan Etika, UII Press, Yogyakarta, 2009, 
menentukan apakah seseorang tersebut dapat dikategorikan sebagai orang yang tidak mampu dan layak diberikan bantuan layanan hukum secara cuma-cuma. Dijelaskan melalui wawancara dengan Penulis, selama berpraktik sebagai seorang Notaris, sempat beberapa kali ia memberikan jasa pelayanan hukum secara cuma-cuma kepada penghadap tetapi bukan karena tidak mampu, namun karena maksud dan tujuan penghadap yang berkaitan dengan kegiatan sosial (yayasan rumah ibadah) sehingga dengan sukarela tidak meminta honorarium kepada penghadap.

Kewajiban Notaris memberikan jasa hukum secara cuma-cuma kepada masyarakat yang tidak mampu sesuai amanat Pasal 37 ayat (1) UUJN merupakan suatu wujud ibadah dari Notaris itu sendiri (ketaatan kepada Tuhan Yang Maha Esa) dan juga cerminan dari akhlak serta kepribadian Notaris yang baik, yang memang juga diharuskan atau diwajibkan dalam kode etik Notaris. Bahkan, menurut Notaris Rakhmat Mushawwir Rasyidi perlu juga diagendakan untuk dilaksanakan berupa kegiatankegiatan sosial yang bersentuhan langsung dengan masyarakat yang kurang mampu, baik yang berkaitan dengan pelayanan hukum maupun kegiatan-kegiatan sosial lainnya. Hal ini perlu dilakukan sebab Notaris merupakan suatu jabatan yang berkaitan langsung dengan masyarakat umum, sehingga stigma yang ada selama ini bahwa Notaris hanya untuk kalangan-kalangan menengah ke atas dapat dihapuskan (perlunya juga dilakukan sosialisasi Pasal 37 ayat (1) UUJN kepada masyarakat sehingga pasal tersebut bukan hanya sebagai pemanis dalam undang-undang).

Memang selama ini, baik dalam pertemuan, seminar, ataupun upgrading tidak pernah dibahas tentang bagaimana seharusnya sikap Notaris dalam melayani masyarakat yang tidak mampu. Namun walaupun belum pernah dibahas, hal ini benarbenar masuk dalam ranah kode etik kita selaku Notaris. Kode etik adalah hal yang harus dipegang teguh dan junjung tinggi keberadaannya, karena kode etik sudah seperti pedoman bagi Notaris dalam berperilaku sehari-hari tidak menyalahi aturan. Hal ini sebagaimana sumpah jabatan Notaris yang pernah dilakukan semua calon Notaris, bagaimana Notaris berjanji dalam menjalankan tugas jabatannya bersikap adil tanpa membedakan satu orang dengan orang yang lain.

Menurut Notaris Rachmaniar Nurul, H., sejak menjabat sebagai Notaris di tahun 2008 memang belum diatur bagaimana kategori orang yang dapat dibebaskan honorariumnya atau dibantu secara cuma-cuma oleh Notaris. Karena belum diatur hingga saat ini, perlu kiranya hal ini diatur karena Notaris adalah penyedia jasa yang mana kerjanya sama seperti dokter dan pengacara, yang bekerja tidak hanya sebatas tentang pendapatan tapi juga memberikan keseimbangan lain dalam mencapai kesuksesan dalam bekerja itu sendiri. Namun ada sebuah kedilemaan yang sedikit membuat bingung. Hal ini karena kita sebagai Notaris, diangkat oleh negara sebagai pejabat tapi dalam sistem honorariumnya tidak digaji oleh negara. Jadi sulit kiranya dalam menjalankan tugas Notaris harus membebaskan honorarium kepada orang karena dalam pembuatan akta-akta kita perlu pergi ke beberapa instansi terkait perizinan, seperti Kemenkumham, pajak, dan jasa penilai, dari sinilah terdapat cost-cost yang harus dikeluarkan oleh Notaris. Cost-cost yang dikeluarkan Notaris untuk keperluan perizinan 
dari sebuah akta yang dibuatnya, sebenarnya bukan kebutuhan dari Notaris melainkan kebutuhan klien yang menggunakan jasa Notaris. ${ }^{12}$

Memang tidak ada kriteria bagaimana seseorang bisa dibantu secara cuma-cuma. Ini yang menjadikan tidak adanya keseragaman antara satu Notaris dengan Notaris yang lain dalam menentukan orang yang seperti apa yang dapat dibebaskan honorariumnya. Jadi semua itu tergantung bagaimana Notaris melihat seseorang yang datang langsung kepadanya dan menilai apakah seseorang itu layak untuk dibebaskan honorariumnya atau tidak. ${ }^{13}$ Selama ini juga belum ada Notaris yang meminta keterangan miskin untuk bukti bahwa seorang itu patut untuk dibantu secara cuma-cuma atau dibebaskan honorariumnya. Hal semacam itu belum pernah dilakukan oleh Notaris. Jadi benar-benar penilaian bisa atau tidak seseorang dibebaskan honorariumnya berdasarkan subjektifitas Notaris itu sendiri.

\section{Penegakkan Pemberian Sanksi terhadap Notaris yang Tidak Memberikan Jasa Hukum secara Cuma-Cuma Kepada Orang Tidak Mampu}

Pasal 70 huruf b UUJN dan Pasal 16 ayat (1) Peraturan Menteri Hukum dan Hak Asasi Manusia Nomor M.02.PR.08.10 Tahun 2004, menjelaskan serta memberi penegasan bahwa Majelis Pengawas Daerah (MPD) berwenang melakukan pemeriksaan terhadap protokol Notaris secara berkala sebanyak 1 kali selama 1 tahun atau setiap waktu yang dianggap perlu. Majelis atau tim pemeriksa dengan tugas semacam ini hanya ada pada MPD saja, yang memiliki tugas pemeriksaan secara rutin atau setiap waktu yang diperlukan dan dilakukan secara langsung di kantor Notaris yang bersangkutan. Namum perlu diketahui bahwa Tim Pemeriksa ini sifatnya insidentil saja, dibentuk oleh MPD jika diperlukan.

Dalam Undang-Undang Jabatan Notaris, Notaris diwajibkan untuk memberikan pelayanan yang sebaik-baiknya kepada semua masyarakat. Masyarakat yang dimaksud tidak menutup kemungkinan hanya kepada mereka yang mampu dari segi finansial tapi pelayanan yang harus diberikan oleh Notaris juga termasuk mereka yang tidak memiliki kecukupan finansial. Selain bantuan hukum, Notaris wajib memberikan penyuluhan hukum kepada siapa saja yang datang guna memberikan kesadaran hukum bagi terhadap hak dan kewajiban mereka yang ingin menggunakan jasa Notaris.

Jika hal di atas benar-benar dicermati maka tugas dan tanggungjawab sebagai Notaris adalah hal yang berat. Ketika Surat Keputusan Pengangkatan sebagai Notaris turun, saat itu juga seharusnya Notaris melaksanakan janji sebagaimana telah diucapkannya. Sanksi yang akan dikenakan oleh Notaris ketika melanggar undangundang bukan hanya sanksi hukum positif, namun juga sanksi moral yang diterima dari masyarakat dan tentu saja sanksi spiritual oleh Tuhan Yang Maha Esa, karena pada saat diangkat sumpahnya Notaris disumpah berdasarkan agamanya masing-masing dengan menyebut nama-Nya.

Terhadap ketentuan Pasal 37 ayat (1) UUJN yang mengatur tentang “Notaris wajib memberikan jasa hukum di bidang kenotariatan secara cuma-cuma kepada orang yang

${ }^{12}$ Hasil wawancara dengan Rachmaniar Nurul. Notaris/PPAT di Kota Pontianak, 07 Februari 2020.

${ }^{13}$ Ibid. 
tidak mampu" dan apabila melanggar ketentuan ayat (1) tersebut maka akan berakibat hukum terhadap Notaris yang bersangkutan yakni pemberian sanksi berupa peringatan lisan; peringatan tertulis; pemberhentian sementara; pemberhentian dengan hormat; atau pemberhentian dengan tidak hormat."14 Dalam realitanya sudah tentu ada NotarisNotaris yang memberikan jasa pelayanan hukum secara gratis, biasanya terhadap badan atau individu yang memang dianggap tidak mampu atau badan yang bergerak di bidang sosial. Untuk mengetahui hal tersebut memang agak relatif susah, sebab Notaris-Notaris yang memberikan jasa hukum secara gratis atau cuma-cuma biasanya tidak ingin diketahui dengan alasan yang berbeda-beda (beberapa contoh kasus karena sebagai bentuk rasa syukur atau bentuk ibadah kepada Tuhan Yang Maha Kuasa). Terkait dengan pemberian sanksi (Pasal 37 ayat (2) UUJN), sejauh ini peran Majelis Pengawas Notaris sebagai badan yang mempunyai kewenangan dan kewajiban melaksanakan pembinaan dan pengawasan terhadap Notaris, dapat dikatakan bersifat pasif. Pasif sebab tanpa laporan atau aduan masyarakat, Majelis Pengawas tidak akan menindak Notaris yang dianggap tidak melaksanakan ketentuan UUJN, dan sampai saat ini belum pernah ada atau ditemukan aduan terhadap Notaris karena tidak memberikan jasa peelayanan hukum kepada masyarakat secara gratis atau cuma-cuma sebagaimana yang diamanatkan dalam ketentuan Pasal 37 ayat (1) UUJN.

Mekanisme pemberian bantuan hukum secara cuma-cuma dalam jasa pembuatan akta dan jasa kenotarisan lainnya kepada masyarakat tidak mampu untuk saat ini masih berpedoman pada Undang-Undang Republik Indonesia Nomor 2 Tahun 2014 tentang Perubahan Atas Undang-Undang Nomor 30 Tahun 2004 tentang Jabatan Notaris (UUJN) Jo. Undang-Undang Republik Indonesia Nomor 16 Tahun 2011 tentang Bantuan Hukum (UUBH), Peraturan Pemerintah RI Nomor 42 Tahun 2013 tentang Syarat dan Tata Cara Pemberian Bantuan Hukum dan Penyaluran Dana Bantun Hukum secara Cuma-Cuma, dan Kode Etik Notaris.

Jelas tertera dalam Pasal 37 ayat (1) UUJN, "Notaris wajib memberikan bantuan hukum di bidang kenotariatan secara cuma-cuma kepada orang yang tidak mampu." Serta berdasarkan Pasal 3 angka 7 Kode Etik Notaris: "memberikan jasa pembuatan akta dan jasa kenotariatan lainnya untuk masyarakat yang tidak mampu tanpa memungut honorarium." Bantuan hukum secara cuma-cuma memang sulit untuk diimplementasikan. Hal ini disebabkan karena belum adanya aturan dari Ikatan Notaris Indonesia (INI) selaku organisasi yang menaungi Notaris se-Indonesia terkait dengan bagaimana cara dan siapa saja yang dapat dibebaskan honorariumnya atau mendapatkan bantuan hukum secara cuma-cuma. Sehingga jika terjadi kondisi seperti ini, pelaksanaannya dikembalikan ke Notaris yang bersangkutan.

Kondisi yang seperti ini membuat adanya kekosongan hukum tentang bagaimana caranya seorang Notaris memberikan bantuan hukum secara cuma-cuma kepada masyarakat tidak mampu. Tapi oleh Undang-Undang Nomor 16 Tahun 2011 tentang Bantuan Hukum (UUBH) dijelaskan cara untuk mendapatkan bantuan hukum dari Notaris secara cuma-cuma, antara lain:

${ }^{14}$ Lihat di dalam Pasal 37 ayat (2) Undang-Undang Nomor 30 Tahun 2004 tentang Perubahan Atas Undang-Undang Nomor 2 Tahun 2014 tentang Jabatan Notaris. 
1. Pemohon bantuan hukum membuat permohonan tertulis ataupun lisan langsung kepada Notaris yang bersangkutan dengan melengkapi syarat-syarat yang menunjukkan bahwa pemohon adalah tidak mampu secara ekonomi. Permohonan tersebut apabila diterima oleh Notaris maka dapat berlanjut bantuan hukumnya. Apabila si Notaris menolak karena alasan tertentu, pemohon bantuan hukum dapat beralih ke Notaris lain atau bila merasa kecewa dapat mengadukan ke INI dimana pemohon bantuan hukum tersebut berdomisili; atau

2. Pemohon bantuan hukum membuat permohonan tertulis kepada ketua Ikatan Notaris Indonesia cabang dimana Pemohon berdomisili, kemudia Ketua INI akan menunjuk salah satu Notaris untuk membantu pemohon.

Aturan hukum memberikan beban tanggungjawab yang harus diemban oleh Notaris terhadap semua perbuatan hukum yang dilakukannya, namun demikian tidak semua kerugian yang dialami pihak ketiga harus menjadi tanggungjawab Notaris. Bahkan hukum sendiri memberikan batasan tanggungjawab Notaris. Hal ini lah yang dikenal dengan perlindungan hukum terhadap Notaris sebagai pejabat umum yang bertugas memberikan pelayanan kepada masyarakat. Notaris dalam menjalankan tugas dan jabatannya yang berwenang membuat akta otentik dapat dibebani tanggungjawab atas perbuatannya sehubung dengan menolak memberikan bantuan hukum secara cumacuma kepada orang yang tidak mampu. Karena tidak dapat dipaksakan ketika Notaris tidak dapat membantu orang yang tidak mampu secara finansial. Ini disebabkan bahwa biaya Notaris tidak hanya untuk dirinya sendiri melainkan biaya untuk pihak yang terkait, contohnya biaya pendaftaran fidusia.

Sampai saat ini belum ada pengaduan tentang Notaris yang tidak memberikan bantuan hukum secara cuma-cuma kepada masyarakat tidak mampu dan juga tidak ada permohonan dari masyarakat ataupun perorangan yang mengajukan bantuan hukum ke Notaris secara cuma-cuma, artinya jarang orang yang meminta untuk dibebaskan sepenuhnya honorarium Notaris karena mengingat semua ini bukan hanya tentang honorarium Notaris sendiri tapi ada pihak terkait yang harus tetap tidak bisa dibebaskan biayanya, namun jika bernegosiasi atau meminta agar honorarium Notarisnya diturunkan, sering sekali terjadi dan bukan hanya orang yang tidak mampu tapi perseroan terbatas pun sering melakukan negosiasi harga.

Memang sejauh ini tidak ada atau belum ada masyarakat yang mengadukan Notaris yang tidak memberikan bantuan hukum secara cuma-cuma ke Majelis Pengawas Daerah. Tapi ada mekanisme untuk masyarakat tidak mampu yang ingin melapor jika ada Notaris yang menolaknya memberikan bantuan hukum. Apabila ada masyarakat yang tidak mampu merasa tidak dilayani oleh seorang Notaris maka dapat mengajukan pengaduan tertulis dan membawa bukti-bukti awal penolakan Notaris dalam memberikan bantuan hukum secara cuma-cuma kepada Majelis Pengawas Daerah. Setelah menerima pengaduan, maka selambat-lambatnya 7 (tujuh) hari kerja Majelis Pengawas Daerah wajib mengadakan sidang Majelis Pengawas Daerah untuk membicarakan dugaan terhadap pelanggaran tersebut.

Apabila menurut hasil sidang Majelis Pengawas Daerah ternyata ada dugaan kuat terhadap pelanggaran kode etik, maka dalam waktu 7 hari kerja setelah tanggal sidang tersebut, Majelis Pengawas Daerah memanggil notaris yang bersangkutan untuk 
memastikan apakah betul telah terjadi pelanggaran dan memberikan kesempatan kepadanya untuk memberikan penjelasan dan pembelaan. Pertemuan tersebut sekaligus menghasilkan putusan menganai terbukti atau tidaknya pelanggaran atau kode etik serta penjatuhan sanksi terhadap pelanggarnya apabila terbukti. ${ }^{15}$

\section{Penutup}

Implementasi pemberian jasa hukum secara cuma-cuma oleh Notaris kepada orang tidak mampu saat ini telah berjalan sebagaimana amanat Pasal 37 ayat (1) UUJN, namun dalam praktiknya Penulis menemukan beberapa karakteristik pelaksanaan yang berbedabeda antara Notaris satu dengan Notaris lainnya. Hal ini disebabkan belum adanya standarisasi tentang kategori-kategori seseorang dapat dikatakan tidak mampu, hal ini penting sebab Notaris juga dituntut untuk jeli dan dapat mengenali penghadap yang datang kepadanya. Berdasarkan hasil pengamatan Penulis di lapangan, bahwa pemberian jasa hukum secara cuma-cuma oleh Notaris kepada masyarakat tidak hanya dilakukan berdasarkan kemampuan finansial, namun juga karena maksud dan tujuan penghadap yang berkaitan dengan kegiatan sosial (yayasan rumah ibadah) sehingga dengan sukarela tidak meminta honorarium kepada penghadap.

Terhadap ketentuan Pasal 37 ayat (1) UUJN yang mengatur tentang "Notaris wajib memberikan jasa hukum di bidang kenotariatan secara cuma-cuma kepada orang yang tidak mampu" dan apabila melanggar ketentuan ayat (1) tersebut maka akan berakibat hukum terhadap Notaris yang bersangkutan yakni pemberian sanksi berupa peringatan lisan; peringatan tertulis; pemberhentian sementara; pemberhentian dengan hormat; atau pemberhentian dengan tidak hormat." Terhadap aturan tersebut, Nancy N. Somalinggi, selaku anggota Majelis Pengawas Wilayah Propinsi Kalimantan Timur menyampaikan bahwa, dalam realitanya sudah tentu ada Notaris-Notaris yang memberikan jasa pelayanan hukum secara gratis, biasanya terhadap badan atau individu yang memang dianggap tidak mampu atau badan yang bergerak di bidang sosial. Untuk mengetahui hal tersebut memang agak relatif susah, sebab Notaris-Notaris yang memberikan jasa hukum secara gratis atau cuma-cuma biasanya tidak ingin diketahui dengan alasan yang berbeda-beda (beberapa contoh kasus karena sebagai bentuk rasa syukur atau bentuk ibadah kepada Tuhan Yang Maha Kuasa). Terkait dengan pemberian sanksi (Pasal 37 ayat (2) UUJN), sejauh ini peran Majelis Pengawas Notaris sebagai badan yang mempunyai kewenangan dan kewajiban melaksanakan pembinaan dan pengawasan terhadap Notaris, dapat dikatakan bersifat pasif. Pasif sebab tanpa laporan atau aduan masyarakat, Majelis Pengawas tidak akan menindak Notaris yang dianggap tidak melaksanakan ketentuan UUJN, dan sampai saat ini belum pernah ada atau ditemukan aduan terhadap Notaris karena tidak memberikan jasa peelayanan hukum kepada masyarakat secara gratis atau cuma-cuma sebagaimana yang diamanatkan dalam ketentuan Pasal 37 ayat (1) UUJN.

Perlu diadakan sosialisasi dalam seminar atau upgrading terkait bagaimana orang yang dapat diberikan bantuan hukum secara cuma-cuma oleh Notaris. Dalam 
menentukan orang yang dapat dibantu secara cuma-cuma, apakah perlu orang tersebut membawa surat keterangan bahwa orang tersebut tidak mampu. Serta perlunya peran Majelis Pengawas Notaris yang aktif dalam melakukan pengawasan terhadap Notaris yang tidak mengamanatkan ketentuan Pasal 37 ayat (1) UUJN dan juga sanksi yang sudah ada harus benar-benar diimplimentasikan. Jangan sampai sanksi yang tertera di undang-undang hanya hiasan saja.

\section{Daftar Pustaka}

\section{Buku}

Abdurrahman, Aspek-Aspek Bantuan Hukum di Indonesia, Cetakan Pertama, Cendana Pers, Jakarta, 1983.

Adjie, Habib, Hukum Notaris Indonesia; Tafsir Tematik Terhadap Undang-Undang Nomor 30 Tahun 2004 Tentang Notaris, Cetakan Keempat, Refika Aditama, Surabaya, 2007. Sekilas Dunia Notaris dan PPAT Indonesia (Kumpulan Tulisan), Cetakan Pertama, CV. Mandar Maju, Bandung, 2009.

Ali, Achmad, Menguak Teori Hukum (Legal Theory) Dan Teori Peradilan (Judicialprudence) Termasuk Interpretasi Undang-Undang (Legisprudence), Kencana, Jakarta, 2013.

Aminuddin, Pendidikan Agama Islam Untuk Perguruan Tinggi Umum, Cetakan Kedua, Ghalia Indonesia, Bogor, 2005.

Anand, Ghansham, Karakteristik Jabatan Notaris di Indonesia, Cetakan Pertama, Prenadamedia Group, Jakarta, 2018.

Departemen Pendidikan dan Kebudayaan Republik Indonesia, Kamus Besar Bahasa Indonesia, Balai Pustaka, Jakarta, 1991.

Dwi Saputra, Anke, Jati Diri Notaris Indonesia Dulu, Sekarang, dan di Masa Datang, Gramedia Pustaka, Jakarta, 2009.

Ghofur, Abdul, Lembaga Kenotariatan Indonesia, Perspektif Hukum dan Etika, UII Press, Yogyakarta, 2009.

Kraan, C.A., De Authentieke Akte, Gouda Quint BV, Arnhem, Rotterdam, 1984.

Kusdariny, Eny, Dasar-Dasar Hukum Administrasi Negara dan Asas-Asas Umum Pemerintahan Yang Baik, UNY Press, Yogyakarta, 2011.

Manan, Bagir, Hukum Positif Indonesia, UII Press, Yogyakarta, 2004.

Stroink, F. A. M., dan J. G. Steenbeek, Besturen Door de Overheid, Tjeenk Willink, Deventer, 1996.

Untung, Budi, 22 Karakter Pejabat Umum (Notaris dan PPAT) Kunci Sukses Melayani, CV Andi Offset, Yogyakarta, 2015.

Utrecht, E., Pengantar Hukum Administrasi Negara Indonesia, Cetakan Keenam, Ichtiar, Jakarta, 1999.

Voors, A.W., Het Notariaat en de Plaats van de Notaris in de Samanleving, Preadvis, Tanpa Kota, 1949.

Whitecross Patton, George, A Text-Book of Jurisprudence, Clarendon Press, Oxford, 1953. 